\title{
Chronic Decubitus
}

National Cancer Institute

\section{Source}

National Cancer Institute. Chronic Decubitus. NCI Thesaurus. Code C112115.

A longstanding lesion caused by death of tissue due to external pressure. 